\title{
A Quaker Meeting in Yorba Linda
}

The Richard Nixon Library \& Birthplace, Yorba Linda, California

The little flower of Yorba Linda told the gravestone: "Get thee behind me"

The gravestone told the grass: "I am coming out of you like a shiny tooth"

The grass asked Mrs. Nixon: "Are you dressed for Easter morning?"

Mrs. Nixon told Tricia and Julie: "Girls, your father is sprouting from the grave"

Tricia and Julie told Checkers: "You must rise too, and come away"

Checkers told us: "Why would I rise? You promised to rebury me at the Library and Birthplace. I am still here at the Bide-a-Wee Pet Cemetery in Wantagh, New York, and not one of you has ever been to visit me"

Tricia and Julie told us: "When we were little girls, we spake as little girls, we understood as little girls, we thought as little girls: but when we became Mrs. Edward Cox and Mrs. David Eisenhower, we put away childish things"

Mrs. Nixon told us: "I am Thelma Catherine Ryan, a miner's daughter and a beauty"

The grass told us: "I feel so light without that shiny stone, so green and airy"

The gravestone told us: "The little flower's death is written on my body" 
The little flower of Yorba Linda told us: "I am rising even if Pat and Checkers will not rise with me. How many did we kill in Laos? Think big, for Chrissakes, Henry"

I said: "Dear Friends, will you sit and quake awhile with me? I invite the gravestone, the grass, the beautiful Thelma Catherine Ryan, Mrs. Cox and Mrs. Eisenhower, Checkers sick-at-heart in Wantagh, even Henry, if he wishes, even the shy flower of Whittier, the angry flower of San Clemente, the thwarted flower of Yorba Linda" 